\title{
Pirjo Lyytikäinen
}

\section{Realismia fantasian ja allegorian maisemissa Erich Auerbach, "Helvetin" realismi ja Johanna Sinisalon Linnunaivot}

Artikkelini pohtii realistisen tyylin eli realismin tyylilajin suhdetta fantasiaan ja allegoriaan dramatisoivan rinnastuksen keinoin. Lähtökohtanani on Erich Auerbachin Mimesiksen idea realismista ja erityisesti sen Dante-analyysi, jossa Dantesta ja erityisesti Danten La Divina Commedian (suom. Jumalainen näytelmä, jatkossa Komedia) "Helvetistä" tehdään realismia, vaikka Komedia on lajityypiltään allegoria ja siinä kuvattu maailma puhdasta fantasiaa. Etenen pohtimaan suomalaisen nykyfantasian tapoja yhdistää arkis-raadollista ja fantasiaa analysoimalla Johanna Sinisalon romaania Linnunaivot (2008), jonka pinnan alla vaikuttaa maanpäällisen helvetin idea. Danten Komedian "Helvetti"-osa ja erityisesti Danteen suoraan nojaava Joseph Conradin Heart of Darkness (1899, suom. Pimeyden sydän 1968) ovat Sinisalon romaanin keskeisiä intertekstejä. Kaikki kolme kirjaa ovat matkoja helvettiin.

Auerbachin esittämät realismin kriteerit toimivat heuristisena mallina, joka mahdollistaa Sinisalon fantasian näkemisen myös erilaisten realismien vastakkainasettelun valossa. Tarkastelen lajityyppien ja tyylin/tyylilajin suhteita Auerbachin realismikäsityksen inspiroimana mutta fokusoimalla fantasian ja allegorian realismisuhteeseen. Metodini on eräänlaista dialogista tai dialektista rinnastusta, joka tähtää erojen ja samuuden valaisemiseen sekä sillä tavoin muutoksen havainnollistamiseen. ${ }^{1}$ Artikkelin ydinkysymys voidaan kiteyttää näin: miten realistista fantasia voi olla? Sinisalon romaanin allegorinen reaalifantasia, ${ }^{2}$ joka edustaa yhtä nykyaikaisen allegorisen fantasian tyyppiä, on analyysin pääkohde, mutta tarkoitus on johdattaa teoreettisten kysymysten äärelle - artikkelini kartoittaa alustavasti tutkimuskenttää, jota aion laajemminkin pohtia.

\section{Mimesiksen kysymys: tyylilajit ja lajityypit}

Erich Auerbachin Mimesiksen luomassa realistisen kuvauksen ja tyylilajin kehityskaaressa Danten Komedia on vedenjakaja. Dante näyttäytyy merkkipaaluna, joka johdattaa pois keskiajan mekaanisesta allegoriasta ja kronikkatyyleistä ja viitoittaa tietä sellaiselle realismille, joka täysin toteutuu vasta 1800 -luvulla. ${ }^{3}$ Tämä on merkillistä, kun ajatellaan Komedian kuvaamaa maailmaa. Tuonpuoleisen kuvaus ja allegorian klassikko muuttuu Auerbachilla "maallisten hahmojen ja intohimojen maailmaksi" (Auerbach 1992, 219; 
tästä eteenpäin $\mathrm{M})$ ja sen tekijä maanpäällisen elämän runoilijaksi, kuten varhaisen tutkimuksen otsikko Dante als Dichter der irdischen Welt (1929) jo ilmoitti. Auerbach näki Dantessa abstraktin allegorian lihallistajan, joka loi konkreettisen, ruumiillisrealistisen kuvauksen avulla todentuntuisia hahmoja ja kohtauksia.

Kuvitteellisen maailman tasolla Danten Komedian hallitsevaksi lajityypiksi hahmottuu allegoria, kun lajityypillä tarkoitetaan teoksen kokonaisuutta määrittävää tai dominoivaa maailmojen kuvittelemisen tapaa ja tyyliä. ${ }^{4}$ Auerbachille kirjallisten teosten kuvaamat fiktiiviset maailmat lainalaisuuksineen eivät ole ensisijaisia: sitä on se realistisen mimesiksen potentiaali joka niissä muhii. Mimesiksen Dantea analysoivan luvun hahmottamat realistiset keinot ja piirteet eivät erottele eri lajityyppejä toisistaan vaan kuvaavat realistisen tyylilajin piirteitä - tässä tapauksessa allegorisen lajityypin sisällä.

Tutkimuksessa on kiinnitetty huomiota siihen, että realismin keinot ovat käytössä myös fantasiassa. Tunnettu on Christine Brooke-Rosen (1981) analyysi siitä, miten lajityypilliset fantasiat nojaavat myös realistisen romaanin "mekanismeihin". ${ }^{5}$ Hän tulee siten osoittaneeksi, että nämä piirteet eivät sellaisenaan erottele realismin ja fantasian lajityyppejä. Brooke-Rosen lähestymistapa antaa samalla suuntaa analyysille, jossa lajityyppi määritetään kokonaisuuden ja fiktiivisen maailman tasolla ja katsotaan erikseen, miten tyylilajit toimivat sen sisällä. ${ }^{6}$

Aluksi on nimettävä lajityypit (karkeasti) maailman tasolla. Fantasia lajityyppinä on märitetty suhteuttamalla sen fiktiivisten maailmojen lainalaisuuksia aktuaaliseen maailmaan. ${ }^{7}$ Realismissa "luonnollisuus" (reaalimaailman kaltaisuus), fantasiassa "yliluonnollisuus" (tai reaalimaailmassa mahdottoman läsnäolo) on oletusarvo. ${ }^{8}$ Myös Tzvetan Todorov nojaa yliluonnollisen kysymykseen, vaikka hänen terminsä tällaiselle fantasialle on klassinen, Aristoteleelta periytyvä "ihmeellinen" (le merveilleux). Todorovin "fantasiaksi" (le fantastique) nimittämä epäröinnin laji (kun lukija ei tiedä, onko kerrottu yliluonnollista vai saako se outoudessaan kuitenkin luonnollisen selityksen) on sen sijaan lajina lähes puhtaasti teoreettinen, vaikka tuokin esiin sen, että lukijan pakottaminen epäröintiin toimii usein retorisena tehokeinona. ${ }^{9}$

Nykyisin fantasiaksi mielletään ennen muuta teokset, joissa kuvatun maailman kokonaisuus on yliluonnollinen eli ei noudata kaikkia aktuaalisen maailman lainalaisuuksia. Tämä ei nykykirjallisuuden valossa ole aivan riittävä rajaus: esimerkiksi sellaisten leikillisten "yliluonnollisuuksien" käyttö kuin kuolleet tai syntymättömät kertojina (kuten yksi kertojahahmo Riina Katajavuoren romaanissa Wenla Männistö [2014]), ei vielä tee fantasiaa. Toisaalta W. R. Irwinin lisäkriteeri, jonka mukaan fantasioita ovat vain "mahdottomuuden" loogiseen ja vakuuttavaan kehittelyyn omistautuvat teokset (Irwin 1976, 9), rajaa ulkopuolelle (post)modernin fantasian, jota Irwin nimittää "fantastiseksi". Ehkä parempi olisi viitata kokonaistunnelmaan, joka vaaditaan: fantasia luo jollain tavalla salaperäisen, maagisen maailman. ${ }^{10}$ Kaikkein 
sallivimmissa määrityksissä mukaan lasketaan myös "outo", jossa kummallisuudet ovat jollain tavalla luonnon mahdollisuuksien rajoissa, mutta pitäydyn artikkelissani kokonaisuutta määrittävän yliluonnollisen ja maagisen tunnelman kriteereihin.

On huomattava, että lajityypit käsitetään malleiksi eli nimenomaan "tyypeiksi" eikä luokiksi. Fantasiat ovat yleensä myös allegorisia ja voivat liukua kohden allegorian lajityyppiä, sillä lajityypin määritys ei ole joko/tai-luokittelua vaan prototyyppistä kategoriointia "enemmän tai vähemmän"-logiikalla. ${ }^{11}$ Nojaamalla prototyyppisiin käsitteisiin, jotka perustuvat edustaviin malleihin ja liukuviin tai huokoisiin rajoihin, kuvataan teosten osallisuus eri lajityyppeihin ja suhde eri tyylilajeihin. Kirjallinen teos voi tällaisessa kategoriointijärjestelmässä edustaa melko tasavahvasti kahta lajityyppiä, joten Danten runoelmaa voi tässä artikkelissa esittämäni väljän fantasian rajauksen valossa pitää myös fantasiana. ${ }^{12}$ Yliluonnollisen hyväksyminen ontologisesti osaksi tarinan maailmaa on toisaalta kriteeri, joka näyttää kategorioivan binäärisesti, mutta monissa fantasioissa yliluonnollisen ontologinen status hämärretään ja edellä mainitut leikilliset yliluonnollisuudet viittaavat rajojen liukumiseen.

Allegoria lajityyppinä viittaa teoksiin, joissa teoksen maailman konkretia kokonaisuutena jännittyy analogiseen/metaforiseen projektiosuhteeseen jonkin abstraktimman merkityskentän kanssa. ${ }^{13}$ Danten teoksessa kuvatut hahmot esimerkiksi edustavat hyveitä tai paheita ja kokonaisuus heijastaa maailmanjärjestystä. ${ }^{14}$ Lisäksi olennainen kriteeri on, että konkreettisen lähteen ja abstraktimman kohteen suhde ilmenee tekstissä (nyt ei siis puhuta allegorisuudesta, jonka lukija voi luoda valmiin tekstin ulkopuolisen tulkintamallin kautta). ${ }^{15}$

Edellä esitetyt tarinan maailmaa koskevat kriteerit johtavat toteamukseen, että fantasian ja allegorian lajityypit ovat varsin usein päällekkäisiä: fantastiset allegoriat edustavat monesti sekä fantasian että allegorian lajityyppiä yhtä vahvasti. Realismi lajityyppinä erottuu sen sijaan fantasialle vastakkaiseksi, mutta voi olla jossain määrin yhteensopiva allegorian lajityypin kanssa, vaikka prototyyppiset allegoriat eivät ole realistista lajityyppiä. Kysymys realistisesta tyylistä fantasian ja fantastisen allegorian lajityyppien sisällä sen sijaan on kiinnostava ainakin Dantesta alkaen, mutta muuttuu yhä haastavammaksi nykyfantasiassa. Realismin rajan asettaminen on toisaalta haaste itsessään: jonkinasteinen "realismi" on ymmärrettävän kerronnan edellytys. ${ }^{16}$ Tyylilajina se vaatii kuitenkin tarkempien kriteerien asettamista.

\section{Realismi - Auerbachin kriteerit}

Auerbachin Mimesiksen VIII luvussa analysoidaan kohtausta "Helvetin" 10. laulusta, koska se tuo monia muita Danten runoelman kohtauksia paremmin esiin sen, mitä Auerbach ymmärtää realismilla tyylilajina. Auerbach sivuuttaa analyysissaan surutta Danten allegorisimmat hahmot eikä pohdi groteskin syövereitä, joissa synnit ja niiden 
rangaistus kirjoitetaan ja kirjotaan ihmisruumiisiin. Valitussa kohtauksessa Dante keskustelee kahden tuntemansa historiallisen henkilön kanssa. Valinta korostaa yhteyttä yhteiskunnalliseen todellisuuteen, joka Danten kannalta oli myös aikalaistodellisuutta. Toisin kuin monien muiden Helvetin asukkaiden kohdalla, henkilöiden synti tai sen rangaistus jäävät taka-alalle. Kohtauksen realistisuus näyttää kumpuavan ensinnäkin siitä, että kumpikin kuvattu hahmo on ”yhä sama mies kuin eläessään”. He myös murehtivat ainoastaan maallisia, eivät kärsimiään Helvetin tuskia. Näin tuonpuoleinen ikään kuin sivuutetaan ja fokusoidaan hahmoihin sellaisina kuin he olivat.

Historiallisuus, arkisuus ja valikoimattomuus korostuvat Danten runoelman luonnehdinnoissa. Auerbachin esiin nostamat henkilöhahmot ovat Danten aikalaisia ja lähimenneisyyden hahmoja, eivät niitä sankareita ja pyhimyksiä tai paholaishahmoja, joita "Helvetissä" myös eloisasti kuvataan. Auerbach näkee henkilöhahmot hyvin arkisessa valossa:

Heitä kuvataan varsin usein kursailematta arkisessa, realistisessa elinympäristössään, eikä Dante ylipäänsäkään tunne mitään rajoja vaan kuvaa arkisia, groteskeja ja vastenmielisiä ilmiöitä hyvinkin tarkasti ja suorapuheisesti (M, 204.)

Philippe Hamon $(2009,205)$ on listannut kuusi realismin kriteeriä, joita Auerbach Mimesiksessä eksplisiittisestikin tuo esiin: (1) vakavuus; (2) tyylien (rekisterien) sekoitus; (3) valikoimattomuus (kaikki aiheet ovat sallittuja); (4) figuura (jonka Hamon tulkitsee tarkoittavan kaikkia koherenssia luovia rakenteita/käytäntöjä); (5) tapahtumien sijoittaminen tuntemaamme historiaan/nykyisyyteen; (6) arkielämän kuvaus. Vakavuus realismissa juontaa juurensa kristillisten tekstien toteuttamasta antiikin sääntöjen transgressiosta ja liittyy tyylien sekoittamisen ideaan. ${ }^{17}$ Sivuutan sen ja figuuran artikkelissani ja keskityn jäljelle jääviin neljään kriteeriin. Historiallisuuden/nykyisyyden kriteeri, joka Danten runoelmassa liittyy paitsi jo mainittuun historiallisten henkilöiden kohtaamiseen ja heidän maanpäällisen todellisuutensa kuvauksiin myös Danten poliittisiin visioihin, on olennainen osa nykyistäkin realismin tutkimusta ja Sinisalon romaanin realismia, jonka allegoriakin tähtää nykymaailman ilmiöihin. Tyylien sekoitus, valikoimattomuus ja arki, joita Auerbach kautta Mimesiksen tuo voimakkaasti esiin, ovat nekin edelleen realismi-tutkimuksessa keskeisiä. Kuudes kriteeri, arjen kuvaus, on tavallaan johtotähti, johon valikoimattomuus ja tyylien sekoituskin kytkeytyvät.

Arki on realismin avainsanoja, ja se on nykyisessä realismin ja naturalismin tutkimuksessa keskeinen analyysin kohde ja väline. ${ }^{18}$ Toisaalta arkea on kaikenlaista: Danten, Auerbachin "Danten” ja Sinisalon teosten valossa arki näyttää monet kasvonsa. Danten Helvetin "arjen" groteski raadollisuus jää itse asiassa Auerbachin visiossa sivuseikaksi, vaikka se on linkki, joka usein yhdistää nykyaikaisia "maanpäällisen helvetin kuvauksia” Danteen. Siihen viitataan Linnunaivoissakin. Paradoksaalisesti tämä viittaussuhde 
on osatekijä siinä, että Sinisalon romaani kaikessa banaalia korostavassa realismissaan hahmottuu fantasiaksi ja allegoriaksikin. Pitkään lukija voi lukea sen päätarinaa melko puhtaana realismina, vaikka pienet outoudet alkavat kasaantua ja vihdoin lukijan epäröinti ratkeaa fantasian (Todorovin "ihmeellisen") hyväksi.

Mutta mitä on arki Auerbachille? Danten kuvaaman Helvetin "arki" on oikeastaan rajallisesti ruumiillista tuskaa; kärsimyksen kokemuksellistamista. Auerbach sivuuttaa kuitenkin visiossaan fiktiivisen konkretian, josta on puhe, ja hahmottaa "maallisen elämän runoilijan" muotokuvaa. Arki ja historia kietoutuvat toisiinsa Danten hahmojen maanpäällisen elämän kautta. Yhteiskunnallisuus, historiallisuus ja ajankohtainen todellisuus ovat arjen omin maaperä Auerbachin arvoasteikossa, vaikka kysymys on myös ihmisten vaihtelevasti raadollisesta jokapäiväisestä elämästä. Auerbach ei myöskään arvosta puuduttavaa arkea. Hän korostaa dramaattista, moniaineksista ja ristiriitaista arkea.

Ihanteellinen realistinen kuvaus nojaa Auerbachin mukaan vastakohtaisuuksiin ja moninaisuuteen. Näiden vastakohtien pitää myös näyttäytyä yhteenkietoutuneina ja sekoittuneina. Myös tyylien/rekisterien sekoituksessa, joka on Mimesiksen johtoteema, on kysymys elämän vastakkaisia puolia yhdistävästä, jännitteitä synnyttävästä kokonaisuudesta. Auerbach näkee Danten korkean tyylin ansiona sen, että se on avoin arkisille ilmauksille. Tämä on realististen fiktiivisten maailmojen rakentamisen johtotähti: elämän ilmiöitä on kuvattava monipuolisesti ylevistä tunteista ja filosofisista visioista aina arjen konflikteihin tai syyhyyn asti. ${ }^{19}$ Auerbachin luettelo todellisuuden alueista Danten runoelmassa koskee ihmisen maailmaa:

[S]e on myös todellisuutta jäljentävä taideteos, jossa esiintyvät kaikki mahdolliset todellisuuden alueet: menneisyys ja nykyhetki, ylevä suuruus ja halveksuttava alhaisuus, historia ja taru, tragiikka ja komiikka, ihminen ja maisema. (M, 208.)

Todellisuuden alueiden sensuroimaton esittäminen ja kielen rekistereiden monipuolinen yhdistäminen liittyvät toisiinsa. Danten arvoa lisää kansankielen voimavarojen sumeilematon käyttö, vaikka edelleen on kysymys korkeasta tyylistä - se dominoi mutta ei rajoita. Kuitenkin Auerbach toisella tavoin palauttaa kunniaan antiikin tyylijakoa perustelleen kielellisen ilmaisun ja kuvatun asian yhteensovittamisen.

Auerbach kiinnittää huomiota kykyyn vaihdella sävyä sisällön mukaan: "kulloisenkin kohtauksen sävy on omanlaisensa, erottuu taustastaan ja vaikuttaa toisiin kohtauksiin.” Vertailussa teoksiin, joissa kerrottu ei heijastu kerrontaan eli joissa "[m]itä dramaattisimpiakin tapahtumakäänteitä saatettiin kuvailla kovin jähmeästi ja seikkaperäisesti” (M, 199), Dante esitetään ylivoimaisena tyylin mestarina. Olennaista kuvauksen voiman kannalta on antiteettinen yhdistely, jossa kohtaukset eivät vain seuraa toisiaan parataktisesti (rinnasteisesti). ${ }^{20}$ Auerbach käyttää ilmaisua "elävä vasta- 
kohta”, ja kuvauksesta voidaan päätellä, että sensitiivisyys elämän moninaisuudelle ja sävyjen vaihtelu kuvatun elämän mukaan tuottaa realismin voiman Dantella. Kysymys on psykologisesti ja moraalisesti koskettavasta, vahvoja tunteita herättävästä sisällöstä ja sisällön vaihtelun välittävästä kerronnasta, joka on vastakkainen kronikkatyyliselle kerronnalle. Kertojan ääni on eläytyvä, aidosti "mimeettinen", ja affektiivinen sitoutuminen kerrottuun välittyy lukijalle.

Auerbach on muualla Mimesiksessä korostanut yksityiskohtaisen kuvailun merkitystä, mutta nyt on kysymys siitä, että kuvauksen on mukauduttava kuvattavaan uudella tavalla. ${ }^{21}$ Dramaattista ei voi kuvata lavertelemalla. Nykyteorian valossa voi sanoa, että kokemuksellisuus on Auerbachille arvo. ${ }^{22}$ Realismin ääneenlausumattomaksi kriteeriksi asetetaan tässä samalla voimakkaan tunnevaikutuksen tuottaminen.

Kokemuksellisessa ei ole kysymys vain havainnollisuudesta, vaan affektiivisuudesta, joka kytkeytyy havainnollisuuteen. ${ }^{23}$ Saadakseen aikaan vastaavan reaktion kirjallisuuden jäljittelevän toiminnan pitää edesauttaa lukijakin ikään kuin kokemaan itse: pitää kertoa niin, että lukija voi kuvitella kerrotun. Parhaiten se onnistuu, kun havainnollisuus yhdistyy tunteiden aktivoitumiseen, sillä vain tuntevana ihminen kiinnostuu ja kiinnittyy näkemäänsä ja kuulemaansa. ${ }^{24}$

Se, että kuvauksessa "syntyy lähes kipeän koskettava ja havainnollinen kuva” $(\mathrm{M}, 219)$ on lukijassa syntyvien empaattisten eli peilaavien vaikutusten ja niiden kautta muotoutuvien tunnekokemusten lähde. Auerbachin teoksessa tyylien sekoituksen arvo on paljastaa arjen traagisuus: realistinen tyylilaji murtautuu antiikin ja klassismin asettamista kahleista kuvaamalla tavallisia kärsiviä ihmisiä arkisessa elämässään vakavasti. Jo Aristoteles näki traagisen nimenomaan tunteita herättävänä: yleisössä heräävän pelon ja sälin kautta syntyy tragedian katarttinen vaikutus. ${ }^{25}$ Mimesiksessä realismin traaginen viritys kuvastaa ihmiselämän perustaa mutta samalla ihmisen arvoa: se on osa humanistista ideologiaa ja tuo realismin kriteeriksi myös affektiivisuuden.

\section{Retkeilyä maanpäällisessä helvetissä}

Otettiin ylhäällä tauko, myslipatukka ja vettä. Maisemat olivat melkoiset, mutta muutama minuutti sai riittää. Kahdeksan kilometrin legi oli taimattu kahdeksaan tuntiin. Jo sekin kertoi ettei auttanut istua haaveilemaan. (Jyrki; Linnunaivot, 134; tästä eteenpäin LA.)

Johanna Sinisalon romaani Linnunaivot (2008) valaisee mielenkiintoisella tavalla realismin ja fantasian suhdetta, ja sen tarkasteleminen Auerbachin kriteerien valossa tuo etualalle myös kuvaustyylien ja teoksen ideologian suhteen. Kun keskitytään teoksen päätarinaan (luvuissa 5 ja 6 katsotaan, mitä muuta teoksen rakenne käsittää) arkipäiväiset henkilökertojat hallitsevat lukijan pääsyä tarinamaailmaan. Kerronta nojaa näkökulmatekniikkaan: vuoron perään äänen saavat naispäähenkilö Heidi ja miespäähenkilö 
Jyrki. Heitä kuvataan vaellusretkillä Uudessa-Seelannissa ja Australiassa, ja molempien arkinen perspektiivi ja arkinen kielenkäyttö rajaavat kerronnan realismin piiriin. ${ }^{26}$ Kolmantena näkökulmahenkilönä on Heidin veli, jonka elämä pyörii roskaruoan, makoilun ja yhä vakavammaksi käyvän "arkipäivän terrorin” ympärillä: autojen naarmuttamisesta edetään sammuneen humalaisen polttamiseen. Aluksi lukijan on vaikea sijoittaa tämän Jessen kuvauksia edesottamuksistaan muuhun tarinaan, mutta tämän "linnunaivoisuuden" version merkitys avautuu teoksen loppupuolella.

Päähuomion kerronnassa saa vaellusretkien extreme-arjen inhorealistisuus ja kertojahahmojen ankean realistinen parisuhde. Todellisuuskuva jää kapeaksi, koska henkilö/ kertojahahmojen ajatusmaailmat ja havainnot ovat rajoittuneet. Tietyllä tavalla teoksen juoni muistuttaa TV:n selviytymiskilpailuja, ja etenkin Heidille kysymys on testistä, johon hän alistuu valitsemansa miehen tähden. Maanisesti "koskematonta" luontoa himoitseva ja sen avulla omia rajojaan koetteleva tai ehkä pikemminkin omaa vallanhimoaan tyydyttävä Jyrki kohdistaa sadistisia piirteitä saavan vallanhalunsa myös naiseen. Jyrkin kerrontavuoroissa Heidi on "se"; tutkittava kohde ja esine, jonka suoriutumista epäillään. Vihdoin rääkin keskellä ("Se oli helvetinmoista menoa") tunnustetaan ajatuksissa: "Eikä se inahtanutkaan" (LA, 134). Valtasuhteessa se joka on tunnustanut riippuvuutensa (Heidi on lähtenyt vaellukselle pitäkseen kiinni suhteesta) on vailla valtaa. Jyrkin puheenvuoroissa ei juuri tunne-elämää pohdita, mutta loppupuolella esitetään miete: "Ensi kertaa ymmärrän miten tärkeäksi se on minulle tullut. Ja miten ja miksi olen tuonut sen tänne, pimeyden sydämeen" (LA, 325). Edelleen kuitenkin kiintymyksen kohde on "se" eikä Heidi! Eikä lukija välttämättä ymmärrä Jyrkiä vieläkään. Vaietut tunteet pidetään sitä paitsi edelleen salassa vaelluskumppanilta. Lukijan ei edellytetä tuntevan empatiaa henkilöitä kohtaan, vaikka lukija peilaa koettelemuksiin ja suoriutumiseen liittyviä tunteita. Iljettävät hyönteiset, muta, kuumuus ynnä muut piinat havainnollistetaan kerronnassa tehokkaasti.

Henkilöitä kuvataan "kursailematta arkisessa, realistisessa elinympäristössään” siinä missä Dantenkin kuvauksissa, mutta kirjaimellisemmin, sillä Sinisalon kuvaamat erämaat ovat todellisesta maailmasta, vaikka vertautuminen Danten (ja Danten kuvittajan Gustave Dorén) Helvetin maisemiin alkaa sävyttää kuvausta Tasmaniasta. Auerbachin ajatusta tuskin voi tulkita väitteeksi Danten Helvetistä "arkis-realistisena elinympäristönä" kadotetuille sieluille, mutta Sinisalo keskittyy nykyaikaisen "maallisen vaelluksen" arjen helvetillisiin ja piinallisiin aspekteihin. Seikkailu on banalisoitu: maisemien upeus ja kaikki romanttiset, runolliset tai muuten positiiviset aspektit, joita vaeltaminen luonnossa ja eksoottisessa ympäristössä voisi merkitä, himmenevät olemattomiin. Vaellus on pelkkää suorittamista ja selviytymistä. Linnunaivojen kerronta pyörii kyllästymiseen asti ruumiin eritteiden ja tarpeiden ympärillä ja mudassa rämmitään kuten Danten Helvetin joissakin piireissä, mutta samalla aivan arkisen fyysisesti. Groteskit tai vasten- 
mieliset yksityiskohdat korostuvat: kun Dante puhuu syyhystä, Sinisalo aloittaa hikisistä haisevista miehistä ja etenee kaikkien muidenkin eritteiden ja vaelluksilla ongelmaksi muuttuvien jätteiden kautta kärpäsiä kuhisevaan käytettyyn tamponiin.

Reaaliaika ja historia, jota eletään 2000-luvulla, on Sinisalon tekstissä alati läsnä oleva tausta - paljon vahvemmin kuin Dantella. Ajankohtainen todellisuus ekokatastrofin uhan ja planeetan tilan kuvausten muodossa suorastaan rytmittää päähenkilöiden vaellusta. Myös kouriintuntuvasti eletään nykyaikaa: kaikki tavaramaailman, roskaantumisen ja eläinten häiriintymisen kuvaukset luovat linkkejä ajankohtaisiin ongelmiin.

Kieli on sekoittunut eikä tyylijakoa tietenkään vanhassa retorisessa mielessä noudateta, mutta teksti tuottaa satiirisen kuvan nykykielestä: henkilöhahmojen kieli jäljittelee nykyajan "taviksia”. Kieli ei kuitenkaan yksilöi. Edes Jessen osuus kerronnasta ei niinkään kuvaa yksilöä kuin tietynlaista nuorisotyyppiä. Heidin ja erityisesti Jyrkin kerronnan kautta esitetään suomen kielen muuttuminen englantilaisia teknisiä termejä viliseväksi viidakoksi, mutta ajoittain rekisteriä kohotetaan ja sanastoon hiipii uusia muodosteita. Vaelluksen mutkikkaita paikannimiä sirotellaan tekstiin kuin mantroja. Tavallaan ne edustavat realistiseen kerrontaan tyypillisesti kuuluvaa todellisten paikannimien käyttämistä. Kirjan sisäkansiin painettu kartta Tasmanian vaellusreitistä vielä lisää tätä toden vaikutelmaa. Lukemattomien lukijalle tuntemattomien paikannimien hokeminen luo silti lopulta vaikutelman toisaalta vieraasta ja käsittämättömästä ja toisaalta saman toistumisesta.

Näkökulmien vaihtelusta huolimatta ei korosteta eroa, niin että "kulloisenkin kohtauksen sävy olisi omanlaisensa". Dramaattista vastakohtaa ei synny, vaikka miehen ja naisen vuorottelevat näkökulmat artikuloivat jossain märin sukupuolten välisiä eroja ja muutoksia tunteissa. Heidin kokemus johtaa kohti kasvavaa sivilisaation kaipuuta, luonnonvoimien kammoa ja skepsistä suhteessa Jyrkiin, joka samaan aikaan tuntee suurempaa kiintymystä häntä kohtaan. Jyrki on kuitenkin jumiutunut suorittamiseen ja etsimään jotain "koskematonta", jota ei voi saavuttaa ja joka muistuttaa yhä enemmän pakkomiellettä. Silti lukijaan päin henkilöiden välinen ero kalpenee verrattuna heidän samanlaisuuteensa nykyajan kasvatteina.

Vaikka kysymyksessä on "todellisuutta jäljentävä taideteos" siinä mielessä kuin Auerbach tämän ymmärtää, siinä eivät esiinny "kaikki mahdolliset todellisuuden alueet" eikä maallisen ihmishahmon kuvaus tuota "kipeän koskettavaa ja havainnollista kuvaa", koska tunteet ja draama puuttuvat kerronnasta. Teoksessa ei herätetä "sympatiaa" henkilöhahmoja tai ihmistä kohtaan ylipäänsä. Henkilöt eivät ole kärsiviä tai kun kärsivät ovat itse aiheuttaneet tilansa. He ovat niitä Helvetin asukkeja, joista Auerbach vaikenee: niitä, joille Infernossa vaeltavalta runoilijahahmolta ei heru sympatiaa. He eivät tunne myötätuntoa toisia ihmisiä kohtaan, ja heidän omituinen keskinäinen tunnesuhteensa kylmää lukijaa. Ero naisen ja miehen välillä säilyy silti: erityisesti mies 
edustaa tunnekylmyyttä ja länsimaisen kulttuurin piittaamattomuutta ja uuskolonialistista riistoa, johon liitetään valheellista idealismia.

Elämän rikkaus ja monivivahteinen draama, joiden kuvaajana Auerbach näkee Danten ja parhaat 1800-luvun realistit, ei ole Linnunaivojen johtoajatus. Eikä kysymys ole sensuurista tai tyyliä koskevista, ennalta omaksutuista rajoituksista. Monenlaista kuvataan, mutta monimuotoisuuden ja vaihtelun sijaan syntyy vaikutelma kaiken latistumisesta samaksi: koko sivilisaatio on kuin yhtä kaatopaikkaa, joka levittäytyy luonnon joka kolkkaan. Jesse kuvataan nykykulttuurin roskatuotteena; vaeltajat pikemminkin sen normituotteina. Mutta ero on suhteellinen.

Sensitiivisyys elämän moninaisuudelle tai sävyjen vaihtelu ei ole Sinisalon kerronnan päämäärä, sen enempää kuin psykologinen koskettavuuskaan. Ainakaan myönteisiä tunteita ei lukijassa henkilöhahmoja kohtaan herätetä vaan päinvastoin vaelluksen kronikka kyseenalaistaa heidät ja heidän kauttaan ihmiskunnan. Kuvauksen "jähmeys" ei ole taidon vaan tahdon puutetta. Sinisalon romaanin realismi edustaakin eräänlaista "posthumanistista" eetosta siinä missä Auerbach humanismia: ihmiset, joiden näkökulma ja ajatusmaailma hallitsevat kerrontaa, ovat kiinni arkisissa, pikkumaisissa tai vähäpätöisissä mietteissä. He eivät luo positiivista kontrastia Jessen vastenmieliselle hahmolle. Ihminen kuvataan kaikkea muuta kuin sympaattiseksi lajiksi. Mikään ei voisi olla kauempana Linnunaivojen maailmasta kuin Auerbachin idealisoiva kuvaus Danten realismista: "Tuloksena on kaiken muun voittava välitön elämän tuntu, sekä moninaisena avautuva että tunteita syvästi koskettava ihmisen kuva” (M, 221).

Olennainen ero on paitsi ideologiassa ja ihmiskuvassa, myös lopulta siinä, että Sinisalo ei kirjoita realismin lajityypissä - sitä ei tosin tee Dantekaan, mutta Auerbach lukee Dantea humanistisen realismin ideansa valossa. Sinisalon romaanissa romaanin näköjään realistiseen maailmaan tuodaan lopulta avoimesti yliluonnollinen elementti. Se selittää omalla tavallaan myös ne oudot tapahtumat, joita on aiemmin kuvattu ikään kuin pelkkinä arkielämän mysteereinä.

\section{Fantasiaa sittenkin}

Linnunaivojen nimi viittaa yhdellä tasolla henkilöhahmojen tai nykyihmisten tyhmyyteen. Romaanin miespäähenkilön lempipuheenaiheita on, kuinka sivistys ja ihmiset turmelevat kaiken ja "saastuttavat" pelkällä läsnäolollaan viimeisetkin koskemattomat keitaat, mutta hän itse etsii tuota koskematonta ja puhdasta, ikään kuin vain "muut" saastuttaisivat. Heidi, jolle Jyrki pitää saarnojaan ja jota alistetaan tiukkaan vaelluskuriin ja syytetään jokaisesta laiminlyönnistä, alkaa Tasmaniassa oman roskaamiskapinansa oman tilan ottamisen, joka ei sekään pysy järjen rajoissa. Linnun aivoista on kuitenkin kysymys muissakin merkityksissä. 
Romaanissa kiinnitetään huomio lentokyvyttömään lintuun, keaan, jonka vaeltajat kohtaavat Uudessa-Seelannissa. Koska kuvaus aiemmasta vaelluksesta lomittuu Tasmanian vaelluksen kanssa, tämä vuoristopapukaija kohdataan romaanissa ikään kuin takautuvasti, mutta samalla niin, että se saadaan kytketyksi Tasmaniaan (missä keoja ei esiinny). Lintu esitetään "turmeltuneeksi", kun puistonvartija kieltää Heidiä ruokkimasta sitä: "Kun ne saavat turisteilta liikaa jalostettuja hiilihydraatteja, ne eivät enää jaksa nähdä vaivaa ruokansa eteen. Ja sitten ne kehittävät sijaistoimintoja." (LA, 107.) Ne kuvataan myös "fiksuiksi ja ilkeiksi".

Romaanin ensimmäisiin outouttaviin mutta realismin säilyttäviin kuvauksiin kuuluu Uuteen-Seelantiin sijoittuva kohtaus, jossa Heidi samastuu keaan. Hän kostaa huonosti käyttäytyvälle polttariporukalle heidän häiriköintinsä levittelemällä heidän tavaroitaan pitkin retkeilymajan pihaa:

Nyt minulla oli nokka.

Minulla oli kynnet.

Pörhistin höyheniäni yötuulessa ja yläniityn kalpeankultaisessa kuutamossa.

(LA, 153.)

Tämän jälkeen kea esitellään romaanissa dokumentoiden siteeraamalla (tai muka siteeraamalla) artikkelia, jossa korostetaan linnun ihmisiin vertautuvaa sopeutumiskykyä, kekseliäisyyttä ja opportunismia. Linnusta luodaan jutussa ensin kuva "selviytymisen mestarina" (LA, 155-156), mutta useampaan kohtaan sirotellun artikkelin sata sivua myöhemmin siteeratussa jaksossa se kuvataan vahinkolintuna. Linnun "sijaistoiminnot" käsittävät autojen turmelun ja käytöstä selitetään "fasilitaationa": ”Jotkut teoreetikot pitävät tätä käytöstä tietynlaisena sosiaalisena fasilitaationa, mikä opettaa nuoria yksilöitä koko ajan oppimaan uutta ja sopeuttamaan käytöstään muuttuviin olosuhteisiin.” (LA, 266.) Samalla kea rinnastetaan Jesseen, autojen turmelijaan ja kaikenlaisen ilkivallan elämäntehtäväkseen ottaneeseen joutomieheen. Viimein kea esitetään (lampaiden) tappajana (LA, 311-313).

Romaanin lopussa kean fantastinen mutaatio samastuu demoniseen lintuun, joka sytyttää Jyrkiltä varastamallaan sytyttimellä maastopalon. Jesse kumppaneineen kuvataan samaan aikaan samanlaisen sytyttimen kanssa aikeissa polttaa sammunut juoppo. Näin romaani lopullisesti tuo nykyarkiseen maailmaansa yliluonnollisen ja samalla romaanin allegorisia ulottuvuuksia syventävän rakenteen. Lajityyppi luo myös perspektiivin, jossa auerbachlaisittain ymmärretyn realismin puutteet, kuten psykologian ohuus, miljöökuvauksen latteus ja tapahtumarakenteen toisteisuus ja koskettavuuden kaihtaminen, palvelevat ekokriittisen ja posthumanistisen merkitysalueen rakentumista.

Sinisalon tuotannon yhteydessä voi puhua maagisesta realismista, reaalifantasiasta tai uuskummasta, joille on tyypillistä horjuttaa fantasian ja realismin perinteisiä jakolinjoja. ${ }^{27}$ Fantasiana Linnunaivot sijoittuu joka tapauksessa yhteiskunta- ja ekokriitti- 
sessä nykyfantasiassa suosittuun alalajiin, jossa erillistä fantasiamaailmaa ei luoda, vaan uhkaava ihmeellinen tai yliluonnollinen tuodaan pikku hiljaa osaksi ensisijaista maailmaa, joka on toden kaltainen. ${ }^{28}$ Liika realismi toissijaisissa fantasian maailmoissa saattaa olla lajityyppiä koskeva ongelma, jos uskomme Brooke-Rosen analyysia Sormusten herrasta. Toisaalta yksittäinenkin ontologinen fantasiaelementti realistisessa teoksessa rikkoo lajityypin. Sinisalon teoksessa kuitenkin päätarinaa täydentävät rakenteet luovat kokonaisuuden, johon päätarinan poikkeama sopii.

Selvää on, että kean muuttuminen personoitua pahaa edustavaksi myyttiseksi hahmoksi rikkoo realismin kehyksen. Se riittää lajityypin muutokseen. (Jätän huomiotta ne metafiktiiviset viitteet, joita kean kuvaus sisältää ja jotka johtaisivat ehkä syvempään ambivalenssiin teoksen tulkinnassa.) Vaikka yksittäinen yliluonnollinen tapahtuma aidossa realismissa olisi tyylirikko, se on Linnunaivoissa tosin yllättävä käänne, mutta pohjustettu ja jälkikäteen motivoitu, sekä kaiken lisäksi kokonaisuuden rakentumisen kannalta ratkaiseva pala. Sinisalon romaanissa fantasiajakso on puolihuomaamatta ennakoitu (tässä tulee oikeastaan kuvaan mukaan eräänlainen figuura, mutta ei realismiin sidoksissa oleva). ${ }^{29}$ Kun se esitetään, se aktivoi lukijan muistamaan ne oudot jaksot ja kuvaukset, joita hän ei täysin ole voinut sijoittaa realistiselle jatkumolle. Se valaisee uudelleen kaiken aiemmin kerrotun, aktivoi yhteyden Heidin ja demonisen, luontoa edustavan linnun välille mutta myös Jessen ja kean välille. Se yhdistyy Jyrkin saarnoihin ihmisten piittaamattomuudesta, mutta osoittaa myös Jyrkin olevan osa samaa ihmiskuntaa tuhon tiellä: hänen sytyttimellään kea sytyttää tuhoisan palon.

Kerrotun uudelleenkytkennät johtavat samalla allegorisuuden tielle. Toisilleen henkisesti etäisinä pysyvien kertojien vaelluksesta rakentuu arkisen inhorealismin ylittävä ja sivuuttava toinen kertomus. Siinä merkityspeliin osallistuvat myös Sinisalon romaanin intertekstit.

\section{Linnunaivojen allegorisuus}

Näin ihminen toimii. Ihminen toimii juuri näin. Tietää mitä taivaanrannan takana on, mutta suunta on pidettävä koska se on jäänyt päälle, koska se on päätetty, suunnan vaihtaminen tai takaisin kääntyminen on periksi antamisen merkki, kaikesta tähän asti saavutetusta luopumista.

Sitä mennään ja vauhdilla vaikka hyvin tiedetään mitä on edessä. (LA, 323-324.)

He olivat valloittajia, ja valloittamiseen tarvitaan vain raakaa voimaa - turha kerskailla kenenkään jolla sitä on, sillä voima on pelkkä sattuma joka johtuu toisten heikkoudesta. (Pimeyden sydän, 12; LA, 17.)

Linnunaivot ei ole lajityypillinen allegoria, vaikka sillä on allegorinen ulottuvuutensa. Realistisetkin romaanit tuottavat usein yleisen vision elämästä ja yhteiskunnasta ja siinä kamppailevista voimista, koska henkilöhahmot edustavat näitä voimia ja koska kuvatut 
tapahtumat edustavat (usein pars pro toto -periaatteen mukaan) yhteiskuntaa tai elämää universaalisti. Sinisalon romaanin henkilöt kuvastavat nyky-yhteiskuntaa, ovat tyyppejä enemmän kuin yksilöitä, ja näihin tyyppeihin kohdistuu romaanin kriittinen valaistus. Tässä on jo ero tyypillisiin realismin hahmoihin, joiden yksilöllisyys ja elämänkohtaloiden koskettavuus taataan kerronnan tuottaman havainnollisuuden ja tunnevaikutusten avulla. Kerrotut tapahtumat ja henkilöhahmot pysyvät reaalimaailmassa mahdollisen rajoissa ja havainnollistavat koskettavasti yksilöiden arjen, mutta kertojan metaforinen apparaatti tuottaa projektioon tarvittavan käsitealueen, ${ }^{30}$ jossa kuvattu konkreettinen rinnastuu johonkin abstraktiin ja yhteiskunnalliseen. Sinisalon romaanissa sen sijaan kuvattu konkretia johtaa yleiseen minimoimalla affektiivisuuden ja hahmojen yksilöllisyyden. Lisäksi siinä on rakenne-elementti, joka on tyypillinen allegorioissa.

Toistaiseksi en ole hiiskunut mitään tästä olennaisesta rakennepiirteestä: Sinisalon romaanin läpi kulkee viittausten ja sitaattien verkosto, joka rinnastaa Heidin ja Jyrkin Tasmanian vaelluksen (ja koko vaellusprojektin) Joseph Conradin romaaniin Pimeyden sydän. ${ }^{31}$ Sitaatit romaanin suomennoksesta esitetään toisaalta välikappaleina kerrontavuorojen lomassa, toisaalta Heidin kerrontajaksoissa. Heidi kommentoi tapahtumia Conrad-sitaatein ja myös puhuttelee tekijää ”[v]oi Joseph, Joseph!” (LA, 50). Romaanin allegorisuus rakentuu avoimesti ja merkittävästi Conrad-analogioiden varaan. Se myös päättyy Conrad-sitaattiin, joka ikään kuin kertoo kaiken merkityksettömyydestä luonnon näkökulmasta: "Luonnon kasvoilla ei näkynyt jälkeäkään siitä kaikesta, mitä minulle oli kerrottu tästä merkillisestä tarinasta [- ]" (LA, 331).

Yliluonnollinen mutantti-kea on allegorialle luonteenomainen demoninen hahmo ja tulkintaa vaativa tunnuskuva. ${ }^{32}$ Kean "kertoma" jakso myös osoittaa kytkennän Jessen ja kean välillä. Se on romaanin viimeinen kursiivilla painettu kerrontajakso ja ainoa poikkeama kaavasta, jonka mukaan kursiivijaksot ovat Jessen kerrontaa. Edellinen kursiivijakso kertoo seinänvierustalle nukahtaneen juopon polttamisaikeesta. Kuvaus loppuu siihen, että Jesse vetää taskustaan sytyttimen, "pienen sileän oranssin" (LA, 317). Demonisen linnun jaksossa viitataan samanlaiseen sytyttimeen, jollainen Jyrkin rinkasta on kadonnut: "Se oli vielä hetki sitten näissä kynsissä, auringonlaskun värinen, pieni ja sileä, ja katsokaa nyt." (LA, 329.) Demoninen lintu, joka lentää sytyttämänsä maastopalon yläpuolella, todistaa kuitenkin, että romaanin vaeltajat poimitaan helikopteriin ja palautetaan sivilisaation yhteyteen viime hetkessä, vaikka "[t]ulta on joka puolella, kuumaa puhdistavaa tulta, mustaa hedelmällistä nokea" (LA, 329). Traagista kohtaloa ei päähenkilöille suoda.

Kaiken kaikkiaan demonisen linnun identiteetti jää häilyväksi. Sen kuvataan halunneen tätä symbolista maailmanloppua: "Sydän lyö, se lyö halkeamaisillaan, sillä juuri tätä halusin." Toisaalta on kuin kysymyksessä olisi vain uni: "Hetken tuntuu kuin näkisin unta ja olisin heräämäisilläni, mutta karistan sen mielestäni, sillä tämä on hyvä." Viimei- 
nen lause on alluusio luomiskertomukseen. Luomiskertomuksen sijaan ollaan kuitenkin hävityskertomuksen keskellä. Demoni näkee hävityksen puhdistavana ja hedelmällisenä ja katselee tyytyväisenä lopputulosta: "Teen laiskan kaarroksen kuuman pyörteen nosteessa ja tarkastelen maailmaan jättämääni jälkeä." (LA, 329.) Viimeinen Conrad-sitaatti kommentoi tätä uskoa jälkeen: jälkeä ei jää. Demonilinnun "laiska” liike ja ajatus jäljestä viittaavat Jessen olemukseen ja puheenvuoroihin, joissa tämä mainitsee, että töhrijät "vain jättää jäljen maailmaan" (LA, 139). Roskaruokaa syövä lintumutantti ja ihmismutantti asetetaan analogisiksi.

\section{Yhteenveto}

Vaikka Sinisalon Linnunaivojen fantasiaa ja allegorisuutta on käsitelty edellä vain varsin suurpiirteisesti, näkyviin on tullut artikkelini pääkysymyksen kannalta keskeinen asia: fantasiassa voidaan toteuttaa kuvauksia, jotka ovat tyylilajiltaan hyvinkin realistisia. Irrotettuina teoksen kokonaisuudesta ne usein eivät edes vihjaa teoksen muihin tasoihin. Silti fantasiaa ei voi rakentaa pelkästään tämän tason kuvausten varaan, vaan jokin systemaattinen keino, jolla fantasia ja allegoria tuodaan tekstiin, on tarpeen. Sinisalo tarvitsee Pimeyden sydäntä ja "Helvettiä" allegoriaansa, ja päätarinan allegoriaa tukeva fantasia vaatii arjen keskelle sijoitettuja outouksia, jotta paholais-kea voi lentää. Danten teos toimii toisin päin eli lihallistaa allegoriaa, ja Auerbachin Dante on 1800luvun realismin silmälasein varustetun humanistin luomus, mutta osoittaa tien, jonka kautta filosofinen ja teologinen ajattelu muuttuu koskettavaksi kokemuksellisuudeksi eli kirjallisuudeksi. Sinisalon romaani puolestaan kertoo nykykirjallisuuden ideologisista ehdoista: todellisuuden kuvaus muuttuu armottomaksi kritiikiksi ja satiiriksi nykyisestä maailmanmenosta, kun usko länsimaiseen ihmiseen tai ihmiseen lajina horjuu. Se myös osoittaa, monen kaltaisensa tekstin tavoin, että tietynlaista todellisuutta on kuvattava fantasian ja allegorian keinoin - että realismi ei riitä. Todellisuuden kuvauksessakin tyylilajit ja lajityypit kietoutuvat toisiinsa. Niiden moninaisten suhteiden selventämiseen tarvitaan samalla näitä käsitteellisiä erotteluja.

\section{Viitteet}

${ }^{1}$ Ideana on eräänlaisten "dialektisten kuvien" metodi; inspiraation lähteenä on Walter Benjamin, vaikka en väitä seuraavani häntä millään ortodoksisella tavalla. Ks. Jennings 1987.

${ }^{2}$ Pasi Ilmari Jääskeläisen keksimä termi viittaa arkirealismiin maagisia ja yliluonnollisia aineksia tuovaan fantasian tyyppiin, kuten sen sukulaistermi "maaginen realismi”. Ks. viite 27 tässä artikkelissa.

${ }^{3}$ Auerbach itse näki 1800-luvun realismin lähtökohtanaan (voisi ehkä sanoa, että se oli hänen tulkintahorisonttinsa), mutta olennaista on myös se, että tarkastelusta suljetaan antiikin koominen realismi, joka perustui tiukkaan laji- ja tyylijakoon (tyyli tässä ymmärrettynä rekisteriksi retoriikan traditiossa). Ks. Combe 2009, 196-198 ja Miller 2012. Realismin 
historialliset tyylit rakentuvat siis rekistereiksi ymmärrettyjen tyylien rikkomisista, transgressioista.

${ }^{4}$ Terminologia ei ole vakiintunutta, mutta erottelu tyylilajin (mode) ja lajityypin välillä, jota tässä artikkelissa käytän, on tarkoitettu erottamaan toisistaan teoksen kokonaisuuden tasolla tapahtuvan tarkastelun (lajityypit) ja teosten sisällä mahdollisen ja tavanomaisen vaihtelun ja sekoittumisen (tyylilajit). Olen itsekin käyttänyt termiä tyylilaji myös lajityyppiä kattamaan (Lyytikäinen 2013), mutta nyt siis viittaan tyylilajilla siihen, miten realismia ilmenee fantasian lajityyppiä edustavassa teoksessa, allegoriaa fantasiassa tai päinvastoin jne.

${ }^{5}$ Scifi, joka Brooke-Rosen luokittelussa (ja fantasian laaja-alaisten määritysten mukaan, joita artikkelissani seuraan) on yksi fantasian laji, omaksui hänen mukaansa täysin realistisen romaanin tekniikat (Brooke-Rose 1981, 81-82). Toisaalta Brooke-Rose soveltaa Philippe Hamonin (1982) erottelemien realismin piirteiden listaa käydessään läpi Tolkienin Tarun Sormusten herrasta (eli nykyaikaisen fantasian "perustavan mallin"; Mathews 2002, 54). Sen suhteen hänen johtopäätöksensä on, että liika realismin keinojen käyttö siinä tärvelee fantasian. (Brooke-Rose 1981, 239-255.)

${ }^{6}$ Tyylilajit identifioidaan lajiteoriassa (Alastair Fowler 1997) lajityypeistä käsin, niin että ne ovat "adjektiivisia" suhteessa subjekti-sanaansa (lajityyppiin, josta käsin ne nimetään). Fowler erottelee esimerkiksi tragedian ja traagisen, komedian ja koomisen. Lajityypistä ja tyylilajista voidaan puhua myös fantasian vs. fantastisen ja allegorian vs. allegorisen kohdalla, vaikka tyylilajeina fantastinen tai allegorinen eivät ole vakiintuneita käsitteitä siinä mielessä, että niille yleensä annettaisiin selvät kriteerit tai että niitä käytettäisiin yksiselitteisesti. Realismin suhteen kieli ei puolestaan oikein käänny ilmaisemaan tätä eroa, vaikka kriteereitä on esitetty: on kai puhuttava realistisesta teoksesta ja realistisesta tyylistä.

${ }^{7}$ Marie-Laure Ryanin $(1991,29)$ luokitteluperustetta, jonka mukaan diskurssit voidaan jakaa aktuaaliseen todellisuuteen fokusoiviin tai "perifeerisiä" maailmoja kuvaaviin (joita Ryan nimittää "maailmoja luoviksi), voi pitää myös fantasian teorian yleisenä lähtökohtana (ks. seuraava viite).

${ }^{8}$ Esim. Brian Atteberyn (1980, 2) määritys, johon mm. Sarah Mendlesohnkin (2008) nojaa, kiteyttää tämän: "Any narrative which includes as a significant part of its make-up some violation of what the author clearly believes to be natural law - that is fantasy." W. R. Irwinin $(1976,4)$ alustava määritys on Atteberyn lähtökohta.

${ }^{9}$ Todorov (1970) esittää fantasiaa koskevan teoreettisen mallinsa akselina, jolle kummalliset, realismia horjuttavat tekstit asettuvat: lähtökohtana on epäröinti, ja epäröinnin tilaan jäävät tekstit ovat akselin keskipiste ("puhdas fantasia"), luonnollisen selityksen tarinan loppuun mennessä saavat "oudot" (l'étrange) tarinat toinen ääripää ja yliluonnollisiksi paljastuvat tai jo lähtökohtaisesti "ihmeelliset" tekstit (kuten sadut) toinen ääripää. Brooke-Rose (1981, 82-84) toisaalta huomauttaa, että ajoittain Todorov puhuu fantastisesta ikään kuin koko akselilla, ts. inklusiivisesti.

${ }^{10}$ Richard Mathews $(2002,1)$ kuvaa yleisen laajan fantasiakäsityksen seuraavasti: "most critics agree it is a type of fiction that evokes wonder, mystery, or magic - a sense of possibility beyond the ordinary, material, rationally predictable world in which we live."

${ }^{11}$ Prototyyppisistä vs. binäärisistä kategorioista ks. Ben-Ze’ev 2000, 6-7, 11-12.

${ }^{12}$ Danten Komedia on prototyyppinen allegoria, muttei prototyyppinen fantasia, Taru Sormusten herrasta on nykyfantasian kannalta prototyyppinen fantasia, muttei prototyyppinen allegoria. Allegoriasta lajityyppinä ks. Lyytikäinen 2013, 18-47. 
${ }^{13}$ On ehkä tarpeen huomauttaa, että "teoksen maailman konkretia kokonaisuutena" ei tarkoita yksityiskohtaista vastaavuutta eikä kaikkien tarinamaailman elementtien käännettävyyttä. Allegorian lajityypin rajauksista lisää ks. Lyytikäinen 2013, 30-47.

${ }^{14}$ Mark Turner, joka kirjassaan The Literary Mind näkee allegoriat käsitealueita sekoittavina analogisina projektioina, kuvaa Danten Infernoa seuraavasti: "Dante's Inferno is an encyclopaedic display of local blended spaces, but additionally, at a higher level, it is a single monumental synoptic blended space." (Turner 1996, 63.) Silloin sekoitetaan kohdealue, jossa päähenkilö oppii teologisen ja filosofisen kuvan maailmasta, ja lähdealue, joka on hänen konkreettinen vaelluksensa kuvitelluissa tuonpuoleisen piireissä. Kaikki konkreettisen maailman aspektit sekoittuvat abstraktin kohdealueen piirteisiin (mt. 64).

${ }^{15}$ Erottelusta ks. Lyytikäinen 2013, 25-29. Allegoriatutkimuksessa "allegoresiksen" eli allegorisen tulkinnan ja allegorian eli allegorioiksi kirjoitettujen teosten erottaminen on rutiininomaista. Allegoresis on tietysti täysin legitiimiä ja kiinnostavaa ja voi tuoda esiin tekstin "tiedostamattoman", kaikki ne kulttuuriset yhteydet, joita tekstillä on, ja ne ideologiset olettamukset, joihin se nojaa mutta jotka eivät välttämättä ole tekijän tiedossakaan.

${ }^{16}$ Kognitiiviset uuden ymmärtämisen "kehyksemme" perustuvat kokemusmaailmaamme ja sen todellisuuteen. On myös esitetty kaikkien tekstien asettuvan akselille, jossa realistinen sekoittuu allegoriseen/fantastiseen. Ks. esim. Jane K. Brown (2007) ja Kathryn Humen (1984, 20) kahden impulssin (mimeettisen ja fantastisen) malli.

${ }^{17}$ Auerbachin kirjoitus "Sacrae scripturae sermo humilis" (Dante 1944) tuo esiin kytkennät. Ks. myös Combe 2009, 198-199.

${ }^{18}$ Ks. Rossi 2007, 118-154. Nykytutkimus nojaa arjen käsitteen yhteiskunnalliseen tutkimukseen, mutta tässä tyydyn puhumaan arjesta väljänä jokapäiväisenä käsitteenä, joka saa hyvinkin erilaisia ilmentymiä kirjallisuudessa.

${ }^{19}$ Auerbachin esimerkki Dantelta: "ja anna vain raapia sen, jota syyhy vaivaa" (Dante, "Paratiisi", 17. laulun säe 129).

${ }^{20}$ Parataksis ei itsessään ole pahan alkujuuri (Raamatun parataksista Auerbach ihailee) eikä hypotaksis aina tuota aitoa realismia (antiikin liioiteltu tekstin organisointi tappaa havainnollisuuden), mutta tässä Auerbachin vertailukohtana on juuri kronikkatyylien kömpelö rinnastamiskäytäntö. Ks. tästä Orlando 2009, 221-223.

${ }^{21}$ Antiikin tyylijaon sopivuuden idea (prepon) merkitsi tyylin/rekisterin sovittamista aiheeseen, mutta samalla lajijakoa aiheiden mukaan. Auerbachin realismissa sovittamisen ihanne on sitä, että kaikkia rekistereitä hyödyntävä tyyli mukautuu rajattomasti kulloinkin käsiteltäviin aiheisiin, joita ei myöskään ole rajattu.

${ }^{22}$ Käsitteen toi keskusteluun Monika Fludernik (1996, 12-13 ja 28-30).

${ }^{23}$ Hogan $(2011$, 46-47) katsoo, että tunteita synnyttävät sekä havainnot että aivojen havaintokeskuksia aktivoivat konkreettiset kuvitelmat. Kirjallisen kuvauksen kannalta tämä tarkoittaa, että sen pitää laukaista havainnollinen kuvittelu, jotta se voi vaikuttaa lukijoiden tunteisiin. Vain siis jos mukaan tulee havainnollisuus, affekti on mahdollinen. Nykyaikainen aivotutkimus (peilineuroniteoria) tukee tällaista ajatusta (ks. Iacoboni 2008): teoria itse asiassa antaa uutta pontta Aristoteleen Runousopista ammentavalle mimesis-ajattelulle.

${ }^{24}$ Ks. esim. Ben-Ze'ev 2000, 161-181 ja aivotutkimuksessa Antonio R. Damasio (esim. 1994, 63 ja 2010, 9).

${ }^{25}$ Aristoteles Runousoppi 1449b; 22-28. Ks. myös Halliwell 2012.

${ }^{26}$ Romaanin luvuissa on sekoitettu kronologiaa, niin että ajallisesti myöhäisin vaellus 
Tasmaniassa on tavallaan päätarina ja siihen sekoitetaan (välillä lukijan tarkkaavaisuutta koetellen) kohtauksia aiemmilta vaelluksilta ja matkaan lähtöä edeltävältä ajalta, jolloin päähenkilöt tutustuvat toisiinsa.

${ }^{27}$ Laajasti ymmärtämäni fantasian eri tyyppien tai alalajien ja Linnunaivojen lajisukulaisten pohdinta ei mahdu tähän yhteyteen. Ks. "uuskumman" käsitteestä esim. VanderMeer 2008, johdanto. Sikäli kuin se rajautuu "outoon" eikä "ihmeelliseen/fantastiseen", se ei kuulu väljästi ymmärtämäni fantasian piiriin. "Reaalifantasiasta" esitetyt märitykset kytkevät sen maagiseen realismiin. Sinisaloa(kin) maagisen realismin edustajana tarkastelee esimerkiksi Niina Niskasen pro gradu -tutkielma 2007, jossa myös on puitu tämän fantasian alaisen lajityypin eri märityksiä.

${ }^{28}$ Mendlesohnin (2008, 114-117) luokittelussa Linnunaivot on esimerkki fantasiasta, jossa reaalimaailmaan tunkeutuu häiriötä aiheuttavia voimia, jotka aluksi pysyvät piilossa mutta joiden vaikutus eskaloituu, ja joissa ainakin lukija vakuuttuu häiriöiden yliluonnollisuudesta. ${ }^{29}$ Vrt. Hamonin $(2009,205)$ tulkinta figuurasta koherenssin tekijänä (ks. s. 14 edellä).

${ }^{30}$ Ks. Fauconnier \& Turner 2002.

${ }^{31}$ Allegoria ja sille ominainen intertekstuaalisuus: ks. Lyytikäinen 2013; Quilligan 1979, 97-99.

${ }^{32}$ Allegorian demonisuudesta Fletcher 1964, 25-69.

\section{Lähteet}

Aristoteles 1997. Retoriikka. Runousoppi. Teokset IX. Suom. Päivi Myllykoski ja Paavo Hohti. Selitykset laatinut Juha Sihvola. Helsinki: Gaudeamus.

Attebery, Brian 1980. The Fantasy Tradition in American Literature: From Irving to Le Guin. Bloomington: Indiana University Press.

Auerbach, Erich 1992. Mimesis. Todellisuudenkuvaus länsimaisessa kirjallisuudessa. (Mimesis: Dargestellte Wirklichkeit in der abendländischen Literatur, 1946.) Suom. Oili Suominen. Helsinki: SKS. (=M)

Auerbach, Erich 1944. Neue Dantestudien: Sacrae scripturae sermo humilis; Figura; Franz von Assisi in der Komödie. Istanbul Yazilari; N:o 5. Istanbul.

Auerbach, Erich 1929. Dante als Dichter der irdischen Welt. Berlin und Leipzig: Walter de Gruyter \& Co.

Ben-Ze'ev, Aaron 2000. The Subtlety of Emotions. Cambridge, Mass. \& London: The MIT Press.

Brooke-Rose, Christine 1981. A Rhetoric of the Unreal: Studies in Narrative \& Structure, Especially of the Fantastic. Cambridge: Cambridge University Press.

Brown, Jane K. 2007. The Persistence of Allegory: Drama and Neoclassicism from Shakespeare to Wagner. Philadelphia: University of Pennsylvania Press.

Combe, Dominique 2009. Genres et styles chez Erich Auerbach. Paolo Tortonese (éd.), Erich Auerbach: la littérature en perspective. Paris: Presses Sorbonne Nouvelle, 191-202. 
Conrad, Joseph 1988. Pimeyden sydän. (Heart of Darkness, 1902). Suom. Kristiina Kivivuori. Helsinki: Otava.

Damasio, Antonio R. 1994. Descartes' Error: Emotion, Reason, and the Human Brain. New York: G. P. Putnam's Sons.

Damasio, Antonio R. 2010. Self Comes to Mind: Constructing the Conscious Brain. New York: Pantheon Books.

Dante 1997 (1924). Jumalainen näytelmä. (Divina Commedia.) Suom. Eino Leino. Porvoo: WSOY.

Fauconnier, Gilles \& Turner, Mark 2002. The Way We Think: Conceptual Blending and the Mind's Hidden Complexities. New York: Basic Books.

Fletcher, Angus 1964. Allegory: The Theory of a Symbolic Mode. Ithaca, New York: Cornell U. P.

Fludernik, Monica 1996. Towards a 'Natural' Narratology. London \& New York: Routledge.

Fowler, Alastair 1997 (1982). Kinds of Literature: An Introduction to the Theory of Genres and Modes. Oxford: Clarendon Press.

Halliwell, Stephen 2012. Aristotelian Mimesis between Theory and Practice. Saija Isomaa, Sari Kivistö, Pirjo Lyytikäinen, Sanna Nyqvist, Merja Polvinen \& Riikka Rossi (eds.), Rethinking Mimesis: Concepts and practices of Literary Representation. Newcastle upon Tyne: Cambridge Scholars Publishing, 3-24.

Hamon, Philippe 1982. Un discours contraint. Gérard Genette \& Tzvetan Todorov (éd.), Littérature et réalité. Paris: Seuil, 119-181.

Hamon, Philippe 2009. La question des critères. Paolo Tortonese (éd.), Erich Auerbach: la littérature en perspective. Paris: Presses Sorbonne Nouvelle, 203-210.

Hogan, Patrick Holm 2011. What Literature Teaches Us about Emotion. New York: Cambridge University Press.

Hume, Kathryn 1984. Fantasy and Mimesis: Responses to Reality in Western Literature. New York \& London: Methuen.

Iacoboni, Marco 2008. Ihmisten peilaus: Kytkeytymisemme uusi tiede. (Mirroring People: The New Science of How We Connect with Others, 2008.) Suom. Kimmo Pietiläinen. Helsinki: Terra Cognita.

Irwin, W.R. 1976. The Game of the Impossible: A Rhetoric of Fantasy. Urbana, Chicago \& London: University of Illinois Press.

Jennings, Michael W. 1987. Dialectical Images: Walter Benjamin's Theory of Literary Criticism. Ithaca \& London: Cornell University Press.

Lyytikäinen, Pirjo 2013. Leena Krohn ja allegorian kaupungit. Helsinki: SKS. Mathews, Richard 2002. Fantasy: The Liberation of Imagination. New York \& London: Routledge. 
Mendlesohn, Sarah 2008. Rhetorics of Fantasy. Middletown, Connecticut: Wesleyan University Press.

Miller, David 2012. Auerbach's Purgatory: Dante, Ethics and Prepon. Saija Isomaa, Sari Kivistö, Pirjo Lyytikäinen, Sanna Nyqvist, Merja Polvinen \& Riikka Rossi (eds.), Rethinking Mimesis: Concepts and practices of Literary Representation. Newcastle upon Tyne: Cambridge Scholars Publishing, 307-320.

Niskanen, Niina 2007. "Selkärankasi näyttää muuttuneen sellonjouseksi”: maagista rea-

lismia kotimaisessa kirjallisuudessa. Kotimaisen kirjallisuuden pro gradu -tutkielma (painamaton). Helsingin yliopisto.

Orlando, Francesco 2009. Codes littéraires et référents chez Auerbach. Paolo Tortonese (éd.), Erich Auerbach: la littérature en perspective. Paris: Presses Sorbonne Nouvelle, 211-262.

Quilligan, Maureen 1979. The Language of Allegory: Defining the Genre. Ithaca \& London: Cornell University Press.

Rossi, Riikka 2007. Le Naturalisme finlandais. Une conception entropique du quotidien. Helsinki: SKS.

Ryan, Marie-Laure 1991. Possible Worlds, Artificial Intelligence and Narrative Theory. Bloomington \& Indianapolis: Indiana University Press.

Sinisalo, Johanna 2008. Linnunaivot. Helsinki: Teos. (=LA)

Todorov, Tzvetan 1970. Introduction à la literature fantastique. Paris: Seuil.

Turner, Mark 1996. The Literary Mind: Origins of Thought and Language. New York \& Oxford: Oxford University Press.

VanderMeer, Ann \& Jeff (eds.) 2008. The New Weird. San Fransisco: Tachyon Publications. 